\title{
Pensjonisttilværelsen som frivillig?
}

\author{
Jeg har lenge reflektert over hvordan jeg skal gi min nær forestående pensjonisttilværelse et meningsfullt \\ innhold. Med helsen i behold og vissheten om behov for min kompetanse som psykiater og allmennlege \\ fenget ideen om frivillige arbeidsopphold. Som en test tilbrakte jeg derfor min siste overlegepermisjon \\ (fra januar til mai 2012) i Estelí, Nicaraguas tredje største by.
}

Jeg frisket opp mine spanskkunnskaper og oppdaterte meg faglig på spansk ett helt år før utreise. Men mestisenes spansk på vestkysten inneholder $40 \%$ lokale uttrykk som ikke finnes i europeisk spansk - ordene kuttes, uttalen kan være utydelig og er rask. Dette gjorde at mine språklige forberedelser viste seg å være utilstrekkelige. Jeg ble derfor raskere mentalt sliten i sosiale situasjoner og hadde ikke overskudd til å bygge opp et tilfredsstillende nettverk under oppholdet.

I Estelí er det offentlige sosiale liv dominert av religiøse aktiviteter, enten i regi av den katolske kirken eller de tallrike protestantiske sektene. De fristet ikke til kontakt, selv om jeg da ekskluderte meg selv fra en viktig arena for opplevelse av fellesskap.

Arbeidssituasjonen, med stort daglig innrykk av pasienter med uoverkommelige hjelpebehov og mangel på muligheter for seriøs utredning og behandling, opplevde jeg som faglig og mentalt krevende. Jeg hadde kun én kollega å forholde meg til, men han var travel, derfor ble kontakten begrenset.

\section{Psykiatriske tjenester i Estelí}

Det er én privat og én statlig psykiatrisk poliklinikk i byen, med én fast ansatt psykiater hvert sted. De skal dekke psykiatritjenester for over 200000 mennesker. Et faglig samarbeid mellom poliklinikkene, et nettverk eller et offentlig støtteapparat for mental helse på kommunalt eller regionalt plan finnes ikke. Jeg var tilknyttet poliklinikken Hospital Escuela de Salud Mental Monseñor Nicolas Antonio Madrigal, eid av den katolske kirken.

Én søndag i måneden dro en offentlig organisert helsebrigade av frivillige til avsidesliggende kommuner i regionen. Den dagen var krevende - med grytidlig avreise og transport på åpent lasteplan over humpete veier gjennom støvete fjellandskap i flere timer.

Etter ankomst ble det tatt et skippertak med tette konsultasjoner for de mange fremmøtte voksne og barn. Det var en eksotisk og faglig spennende arbeidssituasjon, blant annet fordi man her kunne møte mange typer nevropsykiatriske problemstillinger som i Norge behandles i spesialinsitusjoner.

\section{Situasjonen på arbeidsstedet}

Poliklinikken, som lå sentralt $\mathrm{i}$ byen, var åpen fire dager i uken. Arbeidsdagen startet klokken 8 . Konsultasjonen var gratis, men pasientene ble bedt om frivillig å betale 30 córdoba, tilsvarende 7 kroner. Venterommet ble fra klokken 6 fylt opp med mengder av mer eller mindre tålmodige og alvorlig syke, gjerne ledsaget av pårørende. De måtte vente på tur utover formiddagen for å få møte psykiateren.

Ofte buste det inn tallrike og tungt bevæpnede politifolk eller fengselsbetjenter for fremstilling av akutt syke eller utagerende fanger i håndjern. Her fikk jeg se fulminante kliniske bilder innen akuttpsykiatrien. Poliklinikken manglet blodtrykksapparater,

\section{«Menneskene er vitale og livsglade trass i tøffe levevilkår»}

medikamenter og førstehjelpsutstyr for å kunne takle slike tilstander, og det var ingen ambulanse i nærheten for å frakte pasienten videre til det somatiske sykehuset fem kilometer unna. Der igjen manglet det psykiatrisk kompetanse.

Min arbeidsplass var også et undervisningssykehus. Derfor var det til enhver tid puljer på åtte psykologistudenter i klinisk praksis på åtte uker, i tillegg innimellom et dusin sykepleierstudenter som trengte psykiatrisk praksis i tre uker. Disse praksisukene syntes å være kaotiske og kontraproduktive på grunn av mangel på egnede lokaler, og studentene ventet flere timer daglig på ansvarlig psykiater, som etter ankomsten hadde nok med å få unna pasientrushet. Studentene var satt til å ta opp anamnestiske data. Det kunne være vanskelig fordi pasientene ofte var uklare om sine familieforhold eller manglet tilstrekkelig språkbegreper. Studentene var i samtalen to eller tre sammen med pasienten. Utspørringen kunne være retningsløs, og det var vanlig med både moralske formaninger og religiøs veiledning. De gjorde sparsomme notater, som etterpå skulle tjene som grunnlag for psykiaterens videre vurdering.Presenterte kasusfremlegg en gang i uken viste at flertallet av studentene ikke syntes å være vant til selvstendig og kritisk tenkning rundt kliniske problemstillinger. De var preget av boklig viten og viste liten evne til aktuell klinisk tilpasning.

\section{Diagnoser og behandling}

Noen diagnosemanual fantes ikke, og differensialdiagnoser ble ikke diskutert. Bakteppet for aktuelle psykiske problemer var som regel pasientenes fortellinger om fattigdom, arbeidsledighet, trangboddhet, alkohol- og narkotikamisbruk, kriminalitet og vold. Mange hadde kroniske lidelser og var dermed velkjente for min kollega. De hyppigst noterte diagnoser var psykose, schizofreni, bipolar lidelse, mani, angst/ depresjon, alkoholisme, substansmisbruk og alskens nevropsykiatriske tilstander. Posttraumatisk stresslidelse så jeg ikke, selv om samfunnsforholdene skulle tilsi noe annet.

Behandlingen var overveiende medikamentell. Mye av konsultasjonstiden gikk med til reseptskriving - idet man måtte utstede én resept per medikament for at det skulle kunne utleveres gratis fra det statlige apoteket. Dersom det ikke var tomt på lageret, kom man nokså langt med de for u-land WHO-anbefalte medikamentene haloperidol, klorpromazin, amitryptilin, valproat, difenhydramin. Men de fantes alltid i kun én formulering og styrke. Utenlandske donasjoner kunne bidra til en viss utvidelse av repertoaret, men leveransene var upålitelige eller medikamentene var gått ut på dato. Det gjorde at en pasient med psykose etter tur hadde brukt haloperidol, klorpromazin, risperidon eller olanzapin. De som kunne betale for seg, fikk kjøpt et hvilket som helst medikament i de tallrike private apotekene - med eller uten resept. Noen pasienter, spesielt de fra distriktet, bekreftet at de brukte naturmedisin.

Eventuell psykoterapi besto i lytting, kortvarig støttende terapi og konkret direktiv rådgiving. 
En pensjonert jesuittpater møtte to ganger i uken for å tilby åndelig veiledning. Hans religiøse tilnærming til behandling av psykiatrisk lidelse virket kulturelt tilpasset.

\section{Oppsummering}

Oppholdet mitt var en blandet opplevelse. Nicaraguanernes spontane væremåte, uttalte meddelelsestrang og nysgjerrighet gjør kontakten enkel. Enkelte samtaler med pasientene var nære og tillitsfulle. Temaene var lett gjenkjennbare.

Studentenes livlige og entusiastiske delaktighet i flere konsultasjoner og kasusdiskusjoner var oppkvikkende. De hjalp meg når jeg satt fast i språkproblemer med enkelte pasienter. Den gamle franske og høyst oppegående paterens tilstedeværelse vegg i vegg med mitt kontor føltes betryggende.

Nicaragua er preget av omfattende samfunnsproblemer. Under oppholdet fikk jeg et godt innblikk i følgene av et kronisk vanstyrt samfunn - med blant annet befolkningens manglende trygghet for liv og helse som følge. Sykdom, uansett diagnose eller alvorlighetsgrad, var stort sett et privat anliggende. Å leve i en slik stressende verden hvor også jeg lett kunne ha blitt et offer, lot meg ikke uberørt.

Min alder, språkvanskene og lite sosial og kulturell forankring skapte en fremmedfølelse som gjorde meg til en nokså distansert tilskuer. Jeg kjente meg sårbar, ufri og etter hvert mer kritisk, følelsesmessig lukket, ja nedfrossen overfor meg selv og omverdenen. Jeg ble frarådet spaserturer alene utenfor bykjernen.

Jeg har tidligere hatt arbeidsopphold både i Nicaragua og $\mathrm{i}$ andre fattige land. Denne turen tydeliggjorde for meg i min nåværende livsfase hvilke betingelser som bør være oppfylt for at jeg skulle kunne trives $i$ et fremtidig engasjement $i$ liknende omgivelser.
Jeg mener fremdeles at jeg har forutsetninger for å gi et bidrag til hjelptrengende ute i verden. Da er Nicaragua et velegnet utgangspunkt - landet byr alltid på overraskelser, og menneskene er vitale og livsglade trass i tøffe levevilkår. Det vil være en meningsfull beskjeftigelse for meg i tiden fremover.

\section{Wolfgang-Dirk Pesche}

wolfgang.dirk.peschel@stolav.no

Wolfgang-Dirk Peschel (f. 1945) er lege ved St. Olavs hospital.

Ingen oppgitte interessekonflikter.

Mottatt 29.4. 2014 og godkjent 29.5. 2014. Redaktør: Erlend Hem. 